\title{
IMPACT OF ANTIOXIDANTS SUPPLEMENTATION ON METABOLIC STATUS AND REPRODUCTIVE PERFORMANCE OF ABERDEEN ANGUS COWS DURING SEASONAL THERMAL STRESS IN ARID SUBTROPICAL REGIONS
}

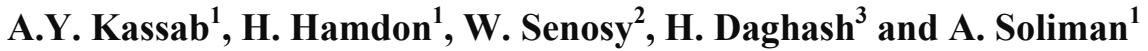 \\ 1- Department of Animal production, Faculty of Agriculture, New Valley University, Al kharga city, New \\ Valley, 51714, Egypt, 2- Department of Theriogenology, Faculty of Veterinary Medicine, New Valley \\ University, Al kharga city, New Valley, 51714, Egypt, 3- Department of Animal production, Faculty of \\ Agriculture, Assiut University, Egypt, 71526 \\ *Corresponding author: Hatem Hamdon: e-mail: hamdon@nv.aun.edu.eg
}

Received: 22/7/2019 Accepted: 5/1/2020

\section{SUMMARY}

This study was performed to investigate the effect of antioxidants supplementation, i.e., vitamin E, selenium (Se) and zinc sulfate administration on metabolic status, biochemical and reproductive performance of Aberdeen Angus cows under hot conditions. Sixteen cows were used and divided randomly into four equal groups (four cows each) and each group was treated for 21 successive days. The first group served as a control. The second group was injected vitamin E and Se at rate of $15 \mathrm{ml} /$ head / twice a week (E Sel group) The third group was supplemented with $200 \mathrm{mg} / \mathrm{head} /$ daily zinc sulphate (Zinc group). Whereas, the fourth one was supplemented with $200 \mathrm{mg} / \mathrm{head} /$ daily zinc sulphate in combination with vitamin E and Sel at rate of $15 \mathrm{ml} /$ head / 15day. Metabolic and antioxidant parameters were measured on a weekly basis for 21 days from the start of treatment until the end of synchronized ultrasonographic estrous cycle. Ultrasonographic examination of follicular number and size was carried out during estrous cycle every three days. Results showed that number of all types of ovarian follicles was high in all treated groups compared to control group. Moreover, number of services per conception recorded higher $(P<0.05)$ values in control group $(1.8)$ compared to treated groups (1.3). Furthermore, glucose concentration $(\mathrm{mg} / \mathrm{dl})$ was high $(P<0.05)$ in zinc group $(66.67 \pm 5.31)$ compared to sel zinc group (58.64 \pm 4.87$)$ and control group $(55.31 \pm 5.09)$ during week 2 post-treatment. Moreover, non-esterified fatty acids $(\mu \mathrm{mol} / \mathrm{l})$ concentration illustrated lower $(P<0.05)$ value in all treatment groups than control group at weeks 2, 3, 4, 5, 6, and 7 post-treatment. Glutathione peroxidase concentration $(\mathrm{GSH}, \mathrm{U} / \mathrm{g} \mathrm{Hb})$ and total antioxidant capacity $(T A C$, mmol/l) were significantly $(P<0.05)$ higher in all treatment groups than that of control group. From the present result it can be concluded that vitamin E, selenium and zinc could improve reproductive performance, metabolic profiles and antioxidant capacity under subtropical heat stress in Aberdeen Angus cows.

Keywords: Antioxidants, supplementation, metabolic status, reproductive performance, thermal stress Aberdeen Angus

\section{INTRODUCTION}

The general characteristic of subtropical climate is directly hot dry summer and mild scanty rain winter. The spring and autumn seasons are usually hot and dry. Thus, the reproductive and productive are greatly hampered. Surrounding temperature, radiant energy, relative humidity and airstream speed are all elements that influence the extent of heat stress (De Rensis and Scaramuzzi, 2003). Therefore, heat stress (HS) gives rise to more conditions than those in the animal thermal neutral zone. The temperature-humidity index (THI) is used widely in hot areas worldwide to evaluate the effect of heat stress on cows (Fuquay, 1981 and Senosy and Osawa 2013). One of the main factors contributing to low fertility in cows is heat stress during the hottest season leading to economic losses in dairy industry (Turk et al., 2015). High-temperature environment could adversely affect conception rates in cows which are conceived during the summer months (Turk et al., 2015). In such condition, heat stress can alter fertility directly by impairing cellular function of reproductive cells. Also, heat stress can indirectly affect reproduction through reduced feed intake with subsequent alterations in energy balance (Wolfenson et al., 2000). Generally, during heat stress, cows have reduced appetite and low dry matter intake which prolongs the period of negative energy balance (NEB), Baumgard and Rhoads, (2013). Directly, heat stress influences follicular development, follicular waves, steroidogenic activity of theca and granulose cells as well as development and function of corpus luteum with a decreased progesterone production (Wilson et al. 1998 and Wolfenson et al. 2002). Low progesterone secretion during the luteal phase can alter oocyte maturation with consequent implantation failure and early embryonic death (Guzeloglu et al., 2001). In addition, heat stress reduced antioxidant activity and caused oxidative stress (Padilla et al., 
2006). Also, decreased feed intake during heat stress causes less frequency of the luteinizing hormone pulse, resulting in longer follicular waves with emergence of smaller dominant follicles (Ronchi et al., 2001 and Sartori et al., 2002). Thus, heat-stressed cows have a higher number of services per conception and lower conception rate (Lucy, 2001).

Reactive oxygen species (ROS) production during oxygen metabolism has required the elaboration of antioxidant defenses that can effectively trap reactive intermediates before causing oxidation to macromolecules or to reduce biomolecule that already have been oxidized (Sordillo and Aitken, 2009). Earlier reports defined antioxidants as any substance that delays, prevents or removes oxidative damage to target molecules (Halliwell and Gutteridege, 2007). Antioxidant defenses are varied, can be either synthesized in vivo or derived from the diet and are localized transiently throughout tissues and different cell types. Both selenium and vitamin $\mathrm{E}$ function to protect biological membranes from oxidative degeneration. Vitamin E and the seleniumcontaining enzyme glutathione peroxidase (GSHpx) are a vital part of the antioxidant system present in all cells (Scherf et al., 1996). Vitamin $\mathrm{E}$ and Se are essential components of the antioxidant defense system and play an important role in growth performance, the immune function, reproductive performance of animals through their participation in critical enzymatic reactions (Aghwan et al., 2016 and Maraba et al., 2018).

The aims of the present study were to characterize metabolic status, ovarian activity and reproductive performance of Aberdeen Angus during summer heat season and to evaluate the impact of some antioxidant's supplementation as selenium, Vitamin E and zinc for alleviating such stress in cows during the stressful hot condition in Egypt.

\section{MATERIALS AND METHODS}

\section{Experimental design:}

This study was executed at the farm of the Department of Animal Production, Faculty of Agriculture, New Valley University, El Kharga city $\left(25^{\circ} 26^{\prime} \mathrm{N}\right.$ and $\left.30^{\circ} 32^{\prime} \mathrm{E}\right)$ throughout the heat stress period from July through August 2017 were used in the experiment. The average ambient temperature and relative humidity were recorded at 10.00 am and $2.00 \mathrm{pm}$ by using mini- maximum thermometer. Then the minimum and maximum averages of temperatures - humidity index (THI) . values were calculated by using the equation according to Mader, Davis et al. (2006).

$\mathrm{THI}=[0.8 \times$ air temperature $]+[(\%$ relative humidity/100) $\times($ air temperature -14.4$)]+46.4$.

A total number of sixteen multiparous nonmilking cycling Aberdeen Angus cows (3-4 years of age and body weight range of $460-520 \mathrm{~kg}$ ) were used in the present study. Cows were healthy and free of bovine viral diarrhea (BVD) virus and infectious bovine rhinotracheitis/infectious pustular vulvovaginitis (IBR/ IPV) virus. Estrus was synchronized in cows by two intramuscular injection of $25 \mathrm{mg}$ dinoprost (Lutalyse, Pfizer manufacturing, Purts, Belgium) 11 days a part. The animals were divided randomly in to four equal groups (four animals each group). Vitamin E and selenium (E Sel group), zinc sulphate (Zinc group), vitamin $\mathrm{E}$ and selenium plus zinc sulphate (E Sel zinc group) were administered ten days before to onset of synchronization protocol till dinoprost second injection (21 days treatment period). All cows were fed on basal diet which was formulated according to NRC, (2000) for Beef cattle. The basal diet consists of $40 \%$ wheat straw and $60 \%$ concentrate fed mixture.

E Sel group were treated with combination of selenium and vitamin E. Each cow injected with 25 $\mathrm{mg}$ sodium selenite and $2250 \mathrm{mg}$ vitamin E two times/week for three weeks (Each $1 \mathrm{ml}$ of Vitesel ${ }^{\circledR}$ contains vitamin E, $150 \mathrm{mg}$ acetate and $1.67 \mathrm{mg}$ sodium selenite). The average length between two successive injections was three days. Zinc group supplemented daily with zinc sulphate $200 \mathrm{mg} /$ heed for three weeks while Sel zinc group was fed daily with zinc sulphate $200 \mathrm{mg} /$ head and injected with 15 $\mathrm{ml}$ viteselen two times per week for three weeks. Control cows were fed a basal diet without any supplementation. Ingredients of concentrate feed mixture presented in Table (1). The chemical composition of concentrate feed mixture and wheat straw are shown in Table (2).

Table 1. Ingredients of concentrate feed mixture

\begin{tabular}{lc}
\hline Items $(\%)$ & \% concentrate mixture \\
\hline Yellow Corn & 55.0 \\
Wheat bran & 21.5 \\
Soybean meal & 20.0 \\
Limestone & 1.5 \\
Dicalcium phosphate & 0.5 \\
Yeast & 0.2 \\
Bicarbonate & 0.3 \\
Sodium chloride & 1.0 \\
\hline
\end{tabular}


Table 2. Chemical composition of concentrate mixture and wheat straw (on DM basis)

\begin{tabular}{lccccccc}
\hline Item & DM & OM & CP & CF & Fat & Ash & NFE \\
\hline Concentrate mixture & 88.76 & 93.79 & 15.76 & 14.12 & 2.39 & 6.21 & 61.52 \\
Wheat straw & 90.35 & 89.05 & 1.79 & 38.71 & 1.12 & 10.95 & 47.43 \\
\hline
\end{tabular}

DM: Dry Matter, CP: Crude Protein, CF: Crude Fiber, NFE: Nitrogen Free Extract

Ultrasonographic examination of ovarian function and reproductive performance traits :

The ovarian structures were investigated through transrectal ultrasonography by a real-time B-mode mobile US unit with a $5 / 7.5-\mathrm{MHz}$ linear array transducer (ECM, Noveko International, Inc., Angoule'me, France). The US equipment was supplied with image freeze and electronic caliper functions for taking measurements. The animals were caliper by the same operator every three days from the day of estrus (day 0 ) till the next estrus at days 0 , $3,6,9,12,1518$ and 0 . Estrus was detected in combination with ultrasonography and by a teaser bull with cows during the experimental period. Follicles were defined as non-echogenic rounded structures with a clear demarcation between the follicular wall and antrum. A corpus luteum (CL) was defined as a grainy echogenic structure that had a well-defined border with the less echogenic ovarian stroma, and in some corpora lutea, there was a nonechodense lacuna (Sheldon et al., 2002). The maximum diameter of each structure was measured using the electronic calliper. When the image of the structure being scanned was not circular, the diameter was estimated by averaging two dimensions at $90^{\circ}$ (Sheldon and Dobson, 2000). The animal considered ovulated when an ovulatory follicle (10-23 mm) detected in the preceding examination disappeared with the formation of ovulation depression and assured by the formation of a CL in the subsequent examination. Ovarian follicles were counted and classified according to their diameter into small $(<5$ $\mathrm{mm})$, medium (5-8 $\mathrm{mm})$, large (9-12) and ovulatory follicles $(>12 \mathrm{~mm})$. The diameter of corpus luteum and size of largest follicle $(\mathrm{mm})$ were recorded.

Cows showed estrus signs after synchronization had been mated with proven fertile bull at the appropriate time (12 hrs after the appearance of estrus signs) for two successive estruses till pregnancy occur. Number of services per conception, first service conception rate and conception rate were calculated.

\section{Blood sampling and plasma analysis:}

Blood samples were collected from each cow through jugular venipuncture early morning into 10 $\mathrm{mL}$ heparinized tubes. The samples were centrifuged at $2000 \times \mathrm{g}$ for $30 \mathrm{~min}$ to obtain plasma at the onset of treatment (1) and then once a week till the end of the synchronized estrous cycle (six weeks) with collectively seven samples per cow during the experimental period. The samples were stored at -20 ${ }^{\circ} \mathrm{C}$ until analysis. Stored plasma samples were analyzed for total protein (TP), glucose (GLU), urea nitrogen (UN), total cholesterol and triglycerides calorimetrically by using commercial test kits and using a UV spectrophotometer (Optizen 3220 UV, Mecasys Co. Ltd, Korea). Non esterified fatty acids (NEFA) were assayed using ELISA kits supplied by Glory Science and conducted in 96-well microplates and read using a microplate reader (Semi Automated ELISA System, Sunrise Absorbance Reader, 811004450, TECAN).

Total antioxidant capacity (TAC) and antioxidant glutathione (GSH) were analyzed calorimetrically using ready-made kits according to the instructions in the enclosed pamphlet of the producing company. Progesterone and estradiol levels were determined using ELISA. The range of the standards used was 0.5 to $50.0 \mathrm{ng} / \mathrm{mL}$. Assay sensitivity was $0.22 \mathrm{ng} / \mathrm{ml}$, and a $50 \%$ effective dose (ED50) was $1.4 \mathrm{ng} / \mathrm{ml}$. Intra- and interassay coefficients of variation were 5.2 and $10.4 \%$, respectively.

\section{Statistical analysis:}

The data were analyzed using a completely randomized design with the GLM procedure of the statistical program SAS/STAT 9.1 (SAS 2004). The differences among treatments were tested using Duncan's Multiple Rang test (Duncan 1955). The model used was $\mathrm{Y}_{\mathrm{ij}}=\mathrm{U}+\mathrm{A}_{\mathrm{j}}+\mathrm{E}_{\mathrm{ij}}$

Where; $Y_{i j}=$ Observation traits, $U=$ overall mean, $\mathrm{A}_{\mathrm{j}}=$ Experimental treatment, $\mathrm{E}_{\mathrm{ij}}=$ Random error.

Differences between treatment means regarding emergence and maximum size of the ovulatory follicles and blood metabolites were determined by independent t-test. Conception rate and service per conception were tested using Chi square test. Analysis of variance with repeated measurements of general linear model were used to investigate the influence of time on each group. Probability values of less than $0.05 \quad(\mathrm{P}<0.05)$ were considered significant. Results are expressed as means \pm SE.

\section{RESULTS}

\section{Climatic conditions:}

The average ambient temperature during the experimental period ranged from 25.2 to $30.3{ }^{\circ} \mathrm{C}$ at $10 \mathrm{am}$ and ranged from 38.3 to $45^{\circ} \mathrm{C}$ at $2: 00 \mathrm{pm}$. While, the respective average of $\mathrm{RH}$ was $10 \%$ and $25 \%$. The average values of THI were between 69.04 to 74.14 at 10.00 am and between 79.43 to 85.46 at 02:00 pm during the whole experimental period. According to the THI values, it is clear that the animals suffered from heat stress during the experimental period, specially at evening.

\section{Ovarian activity and reproductive performance:}

Figure (1A), indicated that number of small follicles $(<5 \mathrm{~mm})$ was higher $(\mathrm{P}<0.05)$ in treated groups as compared with control cows during days nine, 15 and 18 of estrous cycle. At day 15 post- 
estrus, number of small follicles in E sel zinc group $(5.33 \pm 0.23)$ was high $(\mathrm{P}<0.05)$ compared to $\mathrm{E}$ sel group $(4.31 \pm 0.33)$ and zinc group $(3.67 \pm 0.19)$. Medium sized follicles $(5-8 \mathrm{~mm})$ were higher $(\mathrm{P}<0.05)$ in $\mathrm{E}$ sel zinc group treated cows than that of untreated cows during days 3, 6, 9, 12, 18 of estrous cycle and estrus (Fig. 1B). Furthermore, large follicles were higher $(\mathrm{P}<0.05)$ in $\mathrm{E}$ Sel zinc treated cows when compared to control one during days 9 , 12, 15 of estrous cycle and estrus period (Fig. 1C). Large dominant follicles $(>12 \mathrm{~mm})$ number was significantly $(\mathrm{P}<0.05)$ high in $\mathrm{E}$ sel zinc group than untreated cows at days 12 and 15 of estrous cycle and during estrus period (Fig. 1D).

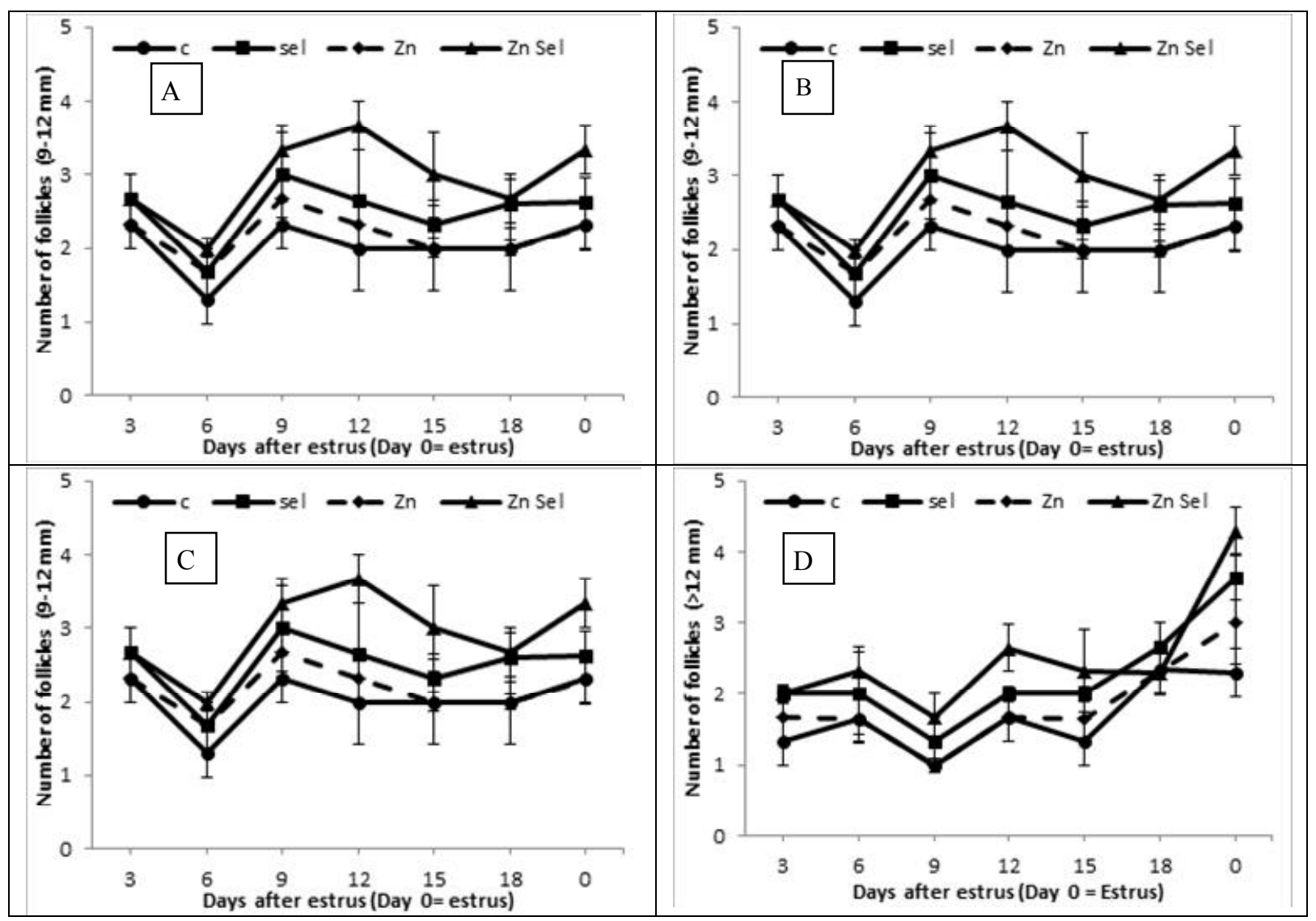

Fig 1. Number of small follicles (<5 mm, A), Medium sized follicles (5 -8 mm, B), large follicles $(9-12$ $\mathrm{mm}, \mathrm{C})$ and Ovulatory follicles $(>12 \mathrm{~mm}, \mathrm{D})$ in control $\mathrm{E}$ selenium $\square$ zinc $>$ and selenium Zinc treated cows during estrous cycle

In Table (3), first service conception rate, second service conception rate and overall conception rate were significantly $(\mathrm{P}<0.05)$ higher in treated groups when compared to control cows. Moreover, number of services per conception was high $(\mathrm{P}<0.05)$ in control group (2.3) if compared to treated groups (1.3). Estradiol concentration $(\mathrm{pg} / \mathrm{ml})$ during detected estrus was higher $(\mathrm{P}<0.05)$ in $\mathrm{E}$ Sel group

$(22.01 \pm 0.11)$ than that of control $(19.73 \pm 0.26)$ and was $(21.28 \pm 0.07)$ in zinc groups, respectively (Table, $2)$. Moreover, corpus luteum size $(\mathrm{mm})$ was higher $(\mathrm{P}<0.05)$ in $\mathrm{E}$ sel zinc group than that of other treated animals. Accordingly, progesterone concentration $(\mathrm{ng} / \mathrm{ml})$ was high $(\mathrm{P}<0.05)$ in $\mathrm{E}$ sel zinc group $(13.71$ $\pm 0.06)$ if compared to control $(12.48 \pm 0.09)$, E sel group (13.28 \pm 0.09$)$ and $\mathrm{Zn}$ group $(12.99 \pm 0.06)$.

Table 3. Reproductive performance of control and treatment Aberdeen Angus cows (mean \pm SE)

\begin{tabular}{lllll}
\hline Item & Control cows & Selenium group & Zinc group & Sel \& Zinc group \\
\hline First service conception rate $\%$ & $25(1 / 4)^{\mathrm{b}}$ & $75(3 / 4)^{\mathrm{a}}$ & $75(3 / 4)^{\mathrm{a}}$ & $75(3 / 4)^{\mathrm{a}}$ \\
Second service conception rate\% & $66.7(2 / 3)^{\mathrm{b}}$ & $100(1 / 1)^{\mathrm{a}}$ & $100(1 / 1)^{\mathrm{a}}$ & $100(1 / 1)^{\mathrm{a}}$ \\
Over all conception rate \% & $75(3 / 4)^{\mathrm{b}}$ & $100(4 / 4)^{\mathrm{a}}$ & $100(4 / 4)^{\mathrm{a}}$ & $100(4 / 4)^{\mathrm{a}}$ \\
$\begin{array}{l}\text { Number of services per conception } \\
\text { Estradiol concentration during }\end{array}$ & $2.3(9 / 4)^{\mathrm{a}}$ & $1.3(5 / 4)^{\mathrm{b}}$ & $1.3(5 / 4)^{\mathrm{b}}$ & $1.3(5 / 4)^{\mathrm{b}}$ \\
$\begin{array}{l}\text { estrus (pg/ml) } \\
\text { Corpus luteum size (mm) during }\end{array}$ & $19.73 \pm 0.26^{\mathrm{a}}$ & $22.01 \pm 0.11^{\mathrm{b}}$ & $21.28 \pm 0.07^{\mathrm{c}}$ & $21.57 \pm 0.07^{\mathrm{bc}}$ \\
$\begin{array}{l}\text { Day 12 midestrus } \\
\text { Progesterone (ng/ml)during Day }\end{array}$ & $22.20 \pm 0.31^{\mathrm{a}}$ & $24.90 \pm 0.38^{\mathrm{b}}$ & $23.87 \pm 0.12^{\mathrm{b}}$ & $27.50 \pm 0.40^{\mathrm{c}}$ \\
$\begin{array}{l}12 \text { midestrus } \\
\text { Values in the }\end{array}$ & $12.48 \pm 0.09^{\mathrm{a}}$ & $13.28 \pm 0.09^{\mathrm{b}}$ & $12.99 \pm 0.06^{\mathrm{b}}$ & $13.71 \pm 0.06^{\mathrm{c}}$ \\
\hline
\end{tabular}

Values in the same row with different superscripts $(\mathrm{a}, \mathrm{b}, \mathrm{c}, \mathrm{d})$ are significant different $(\mathrm{P}<0.05)$ 


\section{Metabolic and biochemical parameters:}

In Fig. (2), blood glucose concentration (mg/dl) was high $(\mathrm{P}<0.05)$ in zinc group $(66.67 \pm 5.31)$ in comparison with $\mathrm{E}$ sel zinc $(58.64 \pm 4.87)$ and control groups $(55.31 \pm 5.09)$ during week two post treatment. At week three, glucose concentration was higher $(\mathrm{P}<0.05)$ in $\mathrm{E}$ sel zinc group than that of other treatments and control. Zinc and E Sel groups had high $(\mathrm{P}<0.05)$ blood glucose concentration during weeks seven and seven when compared to control cows (Fig. 2). Furthermore, data in Fig. (2) showed that total proteins concentration $(\mathrm{g} / \mathrm{l})$ was higher $(\mathrm{P}<0.05)$ in zinc group than control group at week 5, 6 and 7 post treatment. Both concentrations of blood urea nitrogen $(\mathrm{mg} / \mathrm{dl})$ and triglycerides $(\mathrm{mmol} / \mathrm{l})$ in all treatment groups including $\mathrm{E}$ sel, zinc and sel zinc were low $(\mathrm{P}<0.05)$ if compared to control cows at weeks 2, 3, 4, 6 and 7 post treatment (Fig. 3).

Results in Fig. (4) presented that total cholesterol concentration $(\mathrm{mg} / \mathrm{dl})$ was high $(\mathrm{P}<0.05)$ in all treatment groups when compared to control at weeks 5, 6 and 7 post treatment (Fig. 4). Moreover, nonesterified fatty acids $(\mu \mathrm{mol} / \mathrm{l})$ concentration was lower $(\mathrm{P}<0.05)$ in all treatment groups than control at weeks 2, 3, 4, 5, 6, and 7 post treatment (Fig. 4). Also, data in Fig. (4) showed that E sel group had lowest $(\mathrm{P}<0.05)$ concentration of NEFAs at week 6 and 7 post treatment if compared to $\mathrm{E}$ sel, zinc and control groups.

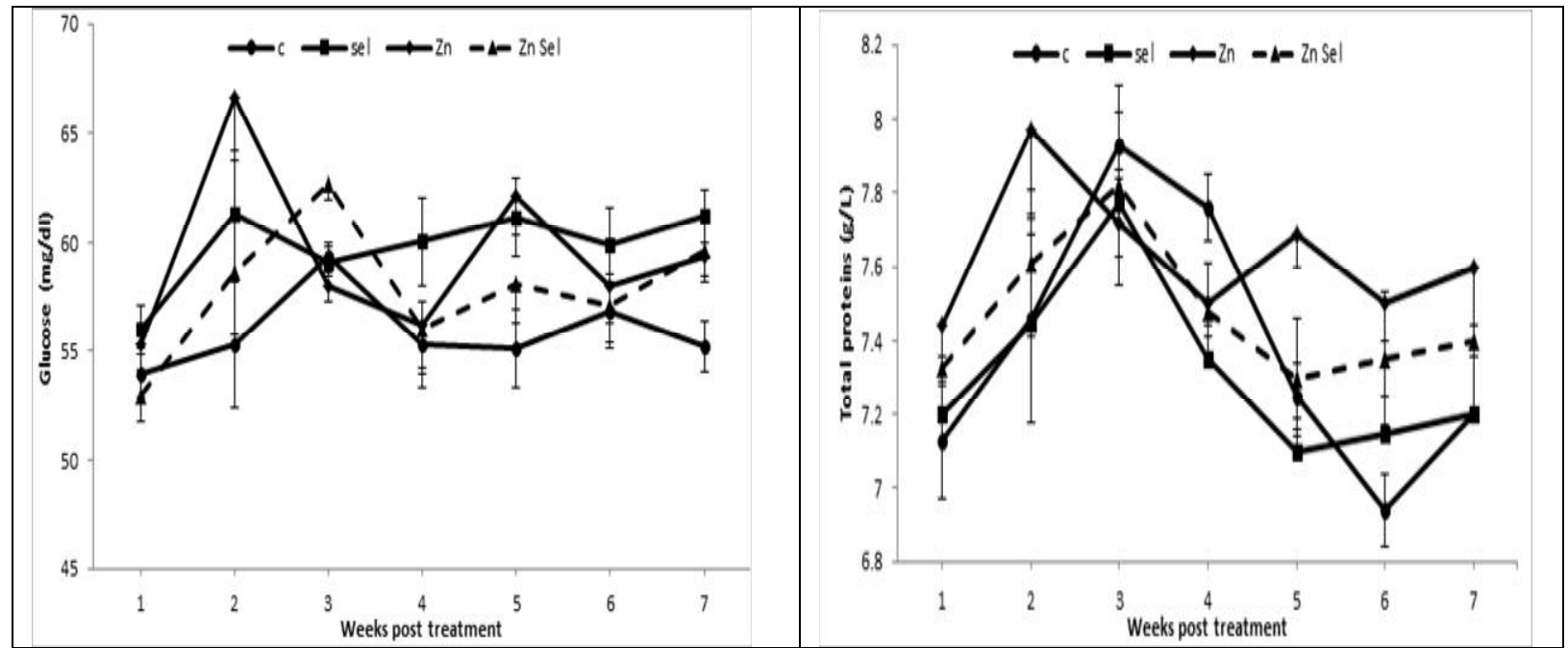

Fig 2. Concentration of blood glucose $(\mathrm{mg} / \mathrm{l})$ and total proteins $(\mathrm{g} / \mathrm{l})$ in control $\bigcirc \mathrm{E}$ selenium $\square$ zinc and selenium Zinc $\triangle$ treated cows

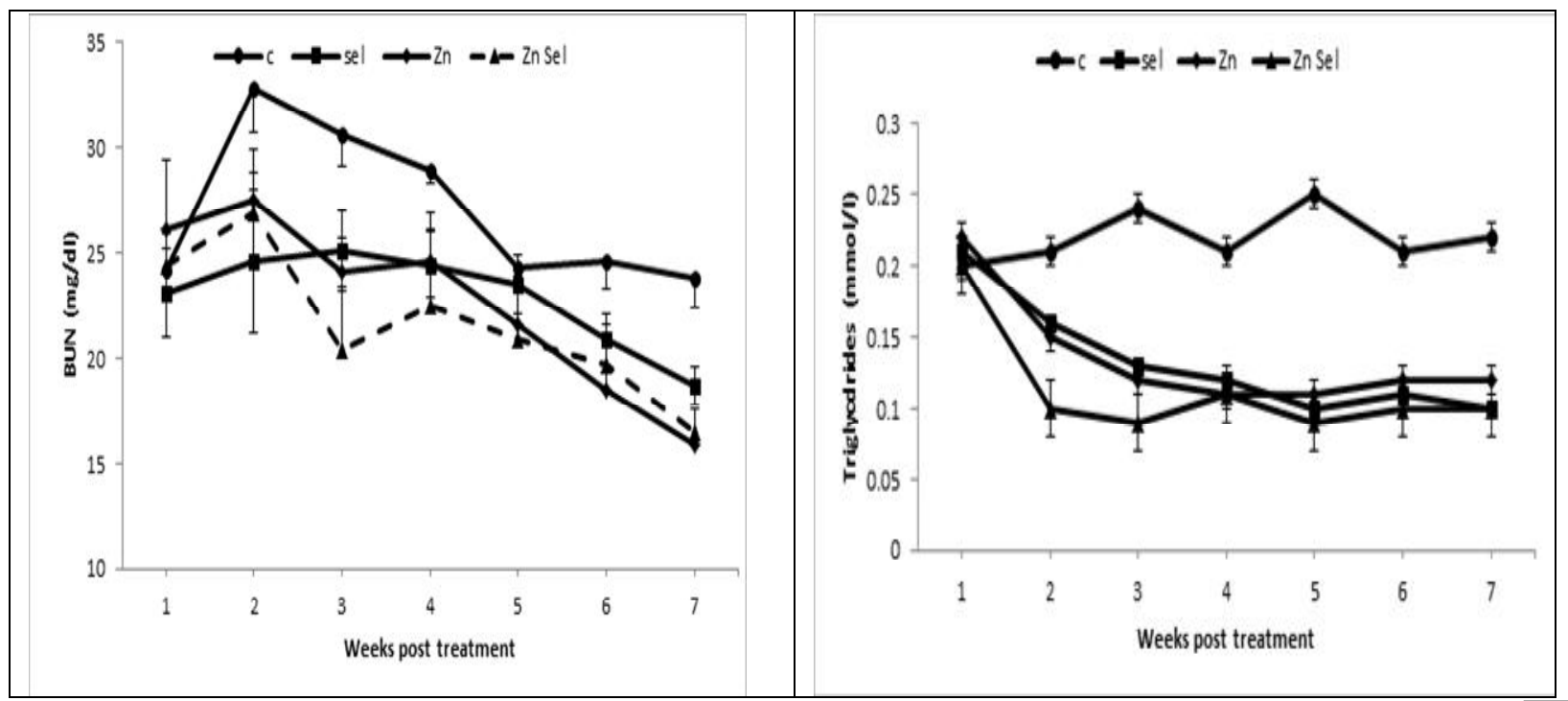

Fig 3. Concentration of blood urea nitrogen $(\mathrm{mg} / \mathrm{dl})$ and triglycerides $(\mathrm{mmol} / \mathrm{l})$ in control $\bigcirc \mathrm{E}$ selenium zinc and selenium Zinc $\triangle$ treated cows 


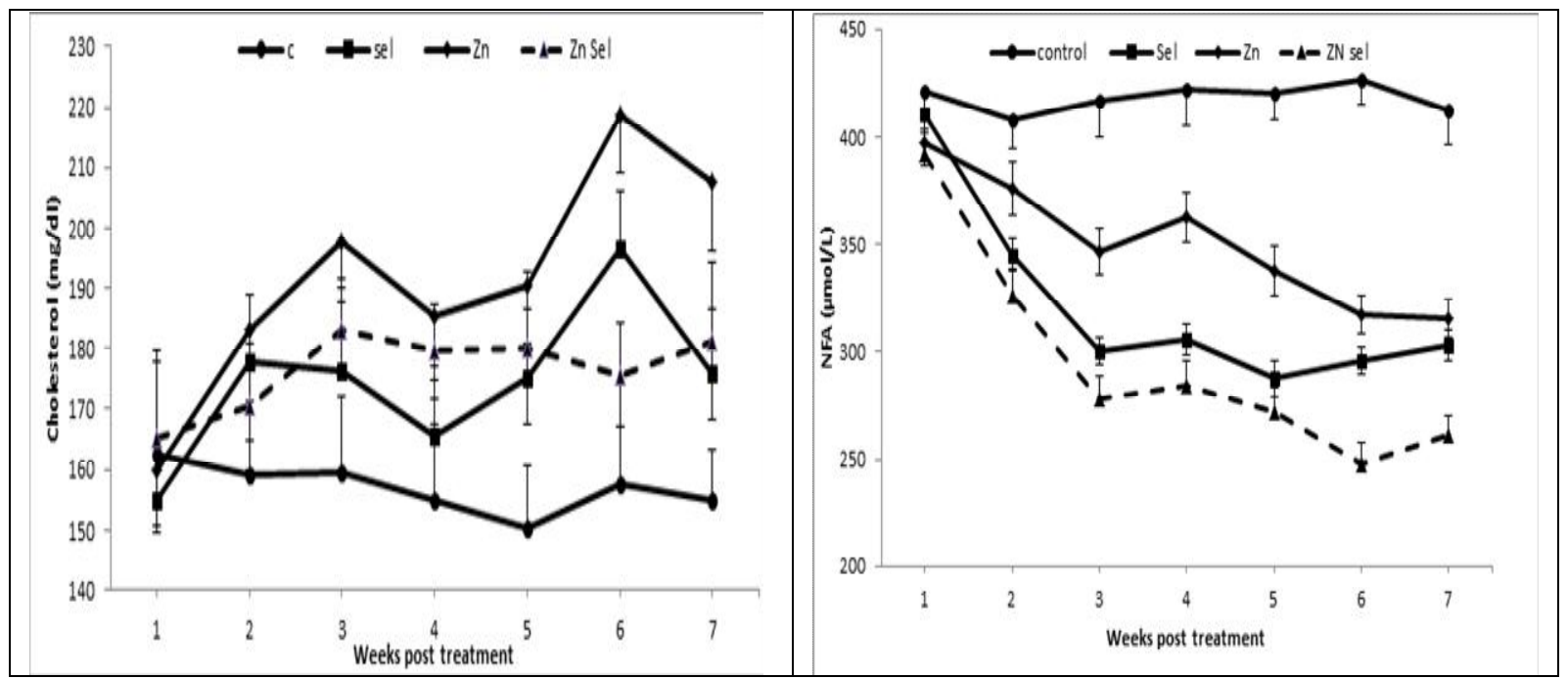

Fig 4. Concentration of total cholesterol $(\mathrm{mg} /$ dland Non estrified fatty acids (NEFA, $\mu \mathrm{mol} / \mathrm{l})$ in control E selenium zinc $\triangle$ and selenium Zinc $\triangle$ treated cows

Oxidant and Antioxidant biomarkers:

In Fig. (5), plasma glutathione peroxidase concentration (GSH, U/g $\mathrm{Hb}$ ) was significantly $(\mathrm{P}<0.05)$ higher in all treatment groups than that of control cows. Total antioxidant capacity (TAC, $\mathrm{mmol} / \mathrm{l})$ concentration was high $(\mathrm{P}<0.05)$ in all treatment groups if compared to control (Fig. 5).
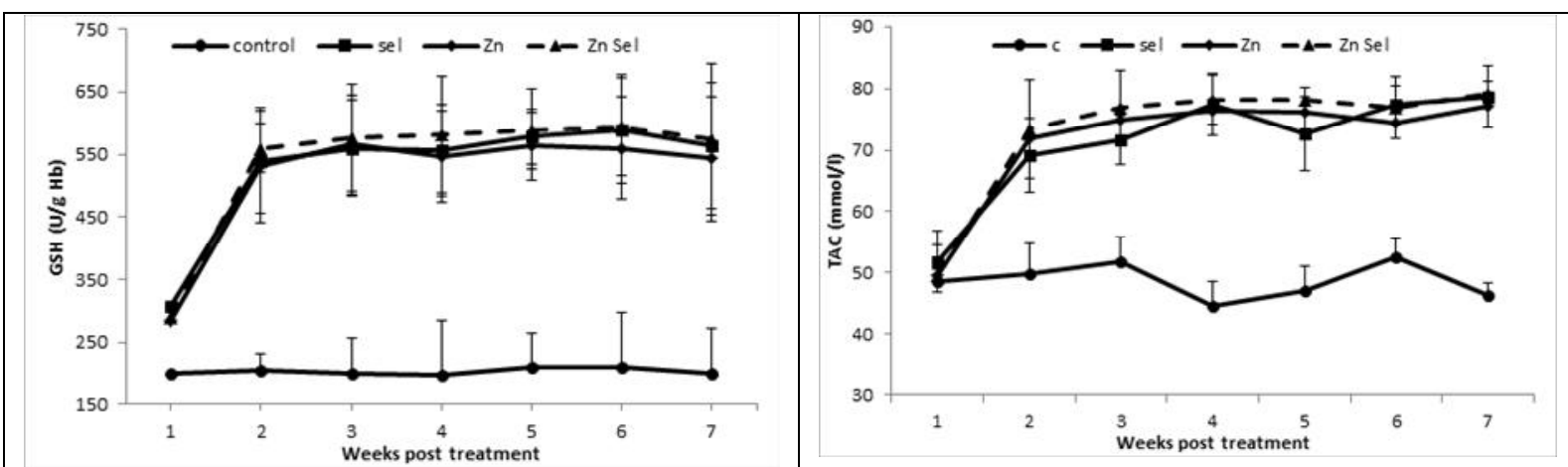

Fig 5. Concentration of reduced glutathione (GSH, u/g Hb) and total antioxidant capacity (TAC, mmol/l) in control E selenium ainc and selenium Zinc $\triangle$ treated cows

\section{DISCUSSION}

Previous reports stated that selenium had antioxidant activity (Gong and Xiao, 2016) and zinc helped to alleviate heat stress (Sheikh et al., 2017). In the present work, selenium, vitamin E and zinc could improve metabolic and reproductive parameters in Aberdeen Angus cows under heat stress. Earlier reports found that mineral and vitamin $\mathrm{E}$ supplementation during per parturient improved reproductive performance (Khan et al., 2015). Furthermore, Campbell and Miller (1998) stated that supplementation with vitamin $\mathrm{E}$ and $\mathrm{Zn}$ improved reproductive performances for dairy cows. Supplementation with selenium, Vitamin E or zinc decreased number of services per conception. These results are concomitant to earlier reports (Arechiga et al., 1994, Kommisrud et al., 2005, Sattar et al., 2007 and Bayril et al., 2015) stating that supplementation of selenium and vitamin $\mathrm{E}$ decrease number of services per conception and increased pregnancy rate. Current research concluded that vitamin $\mathrm{E}$ and selenium and supplementation of zinc sulphate in Aberdeen Angus cows increased conception rate. The present results are concomitant with the previous studies. They stated that pregnancy rate increased after supplementation with vitamin $\mathrm{E}$ and selenium in crossbred cows (Hemingway 2003, Mavi et al., 2006 and Khatti et al., 2017). Higher conception rate may be due to the effect of selenium on establishment of ova and sperm transport (Hemingway, 2003) and improvement of fertilization rate that could be observed with vitamin $\mathrm{E}$ and selenium supplementation in cattle (Segerson et al., 1981). Earlier reports supported the importance of selenium and $\mathrm{Zn}$ and $\mathrm{Mn}$ as their deficiency have been linked to abnormal estrus cycles, impaired ovulation and decreased conception rates (Underwood, 1981 and Hostetler et al., 2003), Concomitantly, Ahola et al., (2004) also found that cows received trace minerals 
$(\mathrm{Zn}, \mathrm{Cu}$ and $\mathrm{Mn}$ ) had higher pregnancy rates than non-supplemented cows. Goat receiving Zinc oxide showed higher pregnancy rate (Kundu et al., 2014) who reported that inclusion of 50,100, and $150 \mathrm{ppm}$ $\mathrm{Zn}$ increased pregnancy rates compared to controls. Improvement of reproductive performances in dairy cows supplemented with $\mathrm{Zn}$ had reported by Manspeaker et al. (1987). This may be due to increase plasma $\beta$-carotene level that correlates directly to the improved conception rates and embryonic development (Hayat et al., 2010).

Feeding trace elements increased ovarian activity in dairy cows (Boland, 2003). Estradiol concentration was high in all treatment groups if compared to control. Antioxidants play a role in gonadotrophic hormone receptors protection form oxidation with subsequent elevation of estrogen secretion (Sergerson et al., 1980) which is important for follicular development. Zinc has a key role in the physiology of the reproductive system (Hafiez et al., 1990). It is known that zinc deficiency particularly in the diet leads to hypogonadism (Nishi, 1996). Om and Chun (1996) showed that zinc deficiency led to an inhibition in LH and estrogen levels. An inspiring clue of the relation between zinc and female reproductive system is that estradiol and progesterone receptors obtained from calf uterus were bound to iminodiacetate-sepharose chelate colons that contained zinc (Vallee and Falchuk, 1993). Moreover, zinc was a significant stimulator in estradiol synthesis is a remarkable finding supporting the relation found between zinc and estrogen (Humeny et al.,1999). Ultrasonic examination of ovarian activity of Aberdeen Angus cows showed a significant difference found among different groups regarding the population of small, medium and large follicles. The lowest population of follicles found in this category was for control. The requirement/involvement of antioxidants is evident as a protective effect of retinol on oocytes during heat stress (Lawrence et al., 2004). Manspeaker et al. (1987) found that supplementation of dairy heifers with $\mathrm{Cu}, \mathrm{Zn}, \mathrm{Mn}, \mathrm{Fe}$ and $\mathrm{Mg}$ (chelated form) exhibited higher number of mature follicles 30-80 days post-partum. On the other hand, follicular and corpus luteum development were not influenced by trace mineral administration while it might increase pregnancy rate in cows (González-Maldonado et al., 2017).

Regarding to vitamin $\mathrm{E}$, there was little information about its effect on corpus luteum functionality. In earlier reports, steroid concentrations were reduced during heat stress in lactating cows (Wilson et al., 1998). Theca and granulosa cell viability were affected by heat stress and reduced steroid concentration resulting in low androstenedione and estradiol production due to low androgen substrate and aromatase activity (Wolfenson et al., 2000). Vierk et al. (1998) demonstrated that vitamin $\mathrm{E}$ supplementation protects the corpus luteum from apoptosis. In the present work, a significant increase $(\mathrm{P}<0.05)$ of progesterone hormone level in Aberdeen Angus cows treated with antioxidant compared with control group. These results agree with Yildiz et al. (2015) who found that there was a significant increase in progesterone in dairy cows that injected with vitamin $\mathrm{E}$ and selenium compered to control. Earlier reports concluded that lower progesterone in hot months might be due to indirect effect of increase ambient temperature that lead to fluctuation in LH level, which has primary stimulation effect on progesterone secretion in domestic animals (Bohr and Dial, 1982). Moreover, zinc plays an important role in regulating progesterone production by luteal cells via involvement of super oxide dismutase (Sales et al., 2011). Zinc is involved in the reorganization of ovarian follicles which are the source of progesterone. This occurs through the involvement of metalloproteinase-2 (MMP-2) enzyme, which is a member of zinc end peptidase family (Gottsch et al., 2000).

Selenium and zinc supplementation increased blood glucose concentration in treatment cows. These results agreed with those reported by Alhidary et al. (2015) concluding that serum concentrations of glucose increased in sheep fed diets supplemented with selenium and vitamin E. On the other hand, Mudgal et al. (2012) and Abdelrahman et al. (2017) found that there was no difference in blood glucose level between treatment and control animals. Contrary to our observations, a declined plasma glucose level was described in buffalo calves supplemented with Se (Singh et al., 2002). Selenium and zinc supplementation elevated total cholesterol concentration. The current results agree with earlier studies showing that supplementation of vitamin $\mathrm{E}$ and vitamin $\mathrm{E}+$ selenium increased significantly cholesterol concentration compared to unsupplemented groups (Avei et al., 2000 and Nayyar et al., 2003). Higher levels of NEFA are indicative of the increasing lipid reserve depletion due to increased energy demand and this was coincided with the findings of Avci and Kizil (2013) in transition cows. Furthermore, the increased NEFA in control group indicate the ability of the body to utilize fat stores for energy responds quickly and dramatically under heat stress in control cows. NEFA concentration in summer increased at calving and remained increased from 2 to 8 weeks post-partum (Turk et al., 2015). It can therefore be assumed that vitamin $\mathrm{E}$, selenium and zinc supplementation may help to improve energy balance in Aberdeen Angus cows.

Plasma metabolites concentration and the plasma total antioxidant status were greatest in cows receiving Se, vitamin $\mathrm{E}$ and zinc supplements (Alhidary et al., 2015 and Shi et al., 2017). In this study, the fact that GSH, and total antioxidant capacity in treatment cows were significantly $(\mathrm{P}<0.05)$ increased as compared with the control indicated that supplementation of Se, vitamin $\mathrm{E}$ and zinc during heat stress can improve the antioxidant status of Aberdeen Angus cows. Endogenous 
antioxidant defense mechanisms in cows can counteract the harmful effects of ROS accumulation. $\mathrm{GSH}$, which is a selenium-dependent antioxidant enzyme, has been studied in the antioxidant defense system of the body higher GSH in selenium and selenium zinc group may be attributed to selenium supplementation if compared to control (Gong and Xiao, 2016).

\section{CONCLUSION}

Supplementation of selenium, vitamin E and zinc during heat stress seasons had a significant impact on reproductive performance in terms of small, medium and large sized follicles and conception rate. Moreover, metabolic and biochemical parameters were improved as well as antioxidant status in the form of TAC and GSH. In conclusion, vitamin E and selenium and zinc or their combination supplementation during heat stress is an effective strategy to improve reproductive performance by enhancing the antioxidant status and nutritional metabolism of Aberdeen Angus cows under heat stress condition.

\section{ACKNOWLEDGMENTS}

The authors thank staff member of Animal Experimental farm belong to Faculty of Agriculture, New Valley University.

\section{REFERENCES}

Abdelrahman, M.M., R.S. Aljumaah, and R. U. Khan, 2017. Effects of prepartum sustained-release trace elements ruminal bolus on performance, colostrum composition and blood metabolites in Najdi ewes. Environmental Science and Pollution Research International, 24 (10): 9675-9680.

Aghwan, Z.A., Sazili, A.Q., K. K. Kadhim, A. R. Alimon,Y. M. Goh, and K. D. Adeyemi, 2016. Effects of dietary supplementation of selenium and iodine on growth performance, carcass characteristics and histology of thyroid gland in goats. Animal Science Journal, 87(5): 690-696.

Ahola, J.K., D. S. Baker, P. D. Burns, R. G. Mortimer, R. M. Enns, J. C. Whittier, T. W. Geary, and T. E. Engle, 2004. Effect of copper, zinc, and manganese supplementation and source on reproduction, mineral status and performance in grazing beef cattle over a two-year period. Journal of Animal Science, 82: 2375-2383

Alhidary, I.A., S. A. Shini, R. A. Jassim, A. M. Abudabos, and J. B. Gaughan, 2015. Effects of selenium and vitamin $\mathrm{E}$ on performance, physiological response, and selenium balance in heat-stressed sheep. Journal of animal science, 93(2): 576-88.

Arechiga, C.F., O. Ortiz, and P. J. Hansen, 1994. Effect of prepartum injection of vitamin $\mathrm{E}$ and $\mathrm{Se}$ on post-partum reproductive function of dairy cattle. Theriogenology, (41): 1251-1258.
Avc1, C., and O. K1z1l, 2013. The effects of injectable trace elements on metabolic parameters in transition cow. Kafkas Universities Veteriner Fakültesi Dergisi, 19 (Supplement A): A73-A78.

Avei, M., J. Z. Karakileik, and R. Kanat, 2000. Effect of Vitamin A, E and selinum on reproductive performance and serum of some biochemical parameters in ewes and birth Weight and survival rate in their lambs. Turkish Journal of Veterinary Animal sciences, (24): 45-50.

Baumgard, L.H., and R. P. Rhoads, 2013. Effects of heat stress on postabsortive metabolism and energetic. Annual Review of Animal Biosciences, 1: 311-337.

Bayril, T.1., A. S. Yildiz, F. Akdemir, C. Yalcin, M. Köse, and O. Yilmaz, 2015. The technical and financial effects of parenteral supplementation with selenium and vitamin e during late pregnancy and the early lactation period on the productivity of dairy cattle. Asian Australasian Journal of Animal Science, 28 (8): 1133-1139.

Bohr, J.M., and O.K. Dial, 1982. Effect of day length on reproductive hormones in the domestic rabbits. Journal of Applied Rabbit Research, (5): 6-7.

Boland, M.P., 2003. Trace minerals in production and reproduction in dairy cows. Advanced Dairy and Technology, (15): 319-330.

Campbell, M. H., and J. K. Miller, 1998. Effect of supplemental dietary vitamin $\mathrm{E}$ and zinc on reproductive performance of dairy cows and heifers fed excess iron. Journal of Dairy Science, 81: 2693- 2699.

De Rensis, F., and R. J. Scaramuzzi, 2003. Heat stress and seasonal effects on reproduction in the dairy cow: a review. Theriogenology, 60: 113911.

Duncan, D.B., 1955. Multiple range and multiple Ftest Biometerics, 11: 1-42.

Fuquay, J.W., 1981. Heat stress as it affects animal production. Journal of Animal Science, 52: 164174.

Gong, J., and M.Xiao, 2016. Selenium and Antioxidant Status in Dairy Cows at Different Stages of Lactation. Biological Trace Element Research, 171(1): 89-93.

González-Maldonado, J., R. Rangel-Santos, R. Rodríguez-de Lara, and O. García-Peña, 2017. Effect of injectable trace mineral complex supplementation on development of ovarian structures and serum copper and zinc concentrations in over-conditioned Holstein cows. Animal Reproduction Science, 181: 57-62.

Gottsch, M.L., W. J. Murdoch, and E. A. Van Kirk, 2000. Tumour necrosis factor alpha upregulates matrix metalloproteinase-2 activity in preovulatory ovine follicles metamorphic and endocrine implications. Reproduction Fertility and Development, 12: 75-80.

Guzeloglu, A., J. D. Ambrose, T. Kassa, T. Diaz, M. J. Thatcher, and W. W. Thatcher, 2001. Long term follicular dynamics and biochemical characteristics dominant follicles in dairy cows 
subjected to acute heat stress. Animal Reproduction Science, 66: 15-3.

Hafiez, A.A., Z. H. el-Kirdassy, N. M. el-Malkh, and E. M. el-Zayat, 1990. Role of zinc in regulating the testicular function. Part 3 . Histopathological changes induced by dietary zinc deficiency in testes of male albino rats. Nahrung, 34: 65-73.

Halliwel,1 B, J. M. C. Gutteridege. Free Radicals in Biology and Medicine, 4th ed. Oxford University Press; 2007.

Hayat, H. M., M. A. Howeda, and A. S. El-Wakeel, 2010. Effect of zinc methionine supplementation on reproductive perform-ance, kid's performance, minerals profile and milk quality in early lactating Baladi goats. World Applied Science Journal, 9: 275-282

Hemingway, R.G., 2003. The influences of dietary intakes and supplementation with selenium and vitamin $\mathrm{E}$ on reproduction diseases and reproductive efficiency in cattle and sheep. Veterinary Research Communication, 27: 159174.

Hostetler, C.E., R. L. Kincaid, and M. A. Mirando, 2003. The role of essential trace minerals in embryonic and fetal development in livestock. Veterinary Journal, 166: 125-139.

Humeny, A., M. Bokenkamp, and H. Thole, 1999. The HDQVH-motif in domain $\mathrm{E}$ of the estradiol receptor alpha is responsible for zinc-binding and zinc-induced hormone release. Mol. Cell Endocrinology, 153: 71-78.

Khan, H.M., T. K. Mohanty, M. Bhakat, A. K. Gupta, A. K. Tyagi, and G. Mondal, 2015. Effect of vitamin $\mathrm{E}$ and mineral supplementation on biochemical profile and reproductive performance of buffaloes. Buffalo Bulletin, 34: 63-78

Khatti, A.S., P. Mehrotra, K. Patel, G. Singh, V. P. Maurya, V. P., A. S. Mahla, R. K. Chaudhari, K. Narayanan, G. K. Das, M. Singh, M. Sarkar, and H. K. Gupta, 2017. Supplementation of vitamin $\mathrm{E}$, selenium and increased energy allowance mitigates transition stress and improves postpartum reproductive performance in crossbred cow. Theriogenology, 104: 142 148

Kommisrud, E, O. Osteras, and T. Vatn, 2005. Blood selenium associated with health and fertility in norwegian dairy herds. Acta Veterinaria Scandinavica, 46: 229-240.

Kundu, M.S., A. K. De, S. Jeyakumar, J. Sunder, A. Kundu, and T. Sujatha, 2014. Effect of zinc supplementation on reproductive performance of Teressa goat, Veterinary World, 7(6): 380-383.

Lawrence, J. L., R. R. Payton, J. D. Godkin, A. M. Saxton, F. N. Schrick, and J. L. Edwards, 2004. Retinol improves development of bovine oocytes compromised by heat stress during maturation. Journal of Dairy Science, 87: 2449-2454.
Lucy, M.C., 2001. Reproductive loss in high producing dairy cattle: Where will it end? Journal of Dairy Science, 84: 1277-1293.

Mader, T. L.,M. S. Davis, and T. Brown-Brandl, 2006. Environmental factors influencing heat stress in feedlot cattle. Journal of Animal Science, 84, 712-719.

Manspeaker, J. E., Robl, M., Edwards, G. H., and W. G. Douglass, 1987. Chelated minerals: Their role in bovine fertility. Veterinary Medicine, 82 : 951-956.

Maraba, K. P., V. Mlambo, A. O. Yusuf, U. Marume, and A. Hugo, 2018. Extra dietary vitamin E-selenium as a mitigation strategy against housing-induced stress in Dohne Merino lambs: Effect on growth performance, stress biomarkers, and meat quality. Small Ruminant Research, 160: 31-37.

Mavi, P.S., G. R. Pangaonkar, and R. K. Sharma, 2006. Effect of vitamin $\mathrm{E}$ and selenium on postpartum reproductive performance of buffaloes. Indian Journal of Animal Science, 76(4): 308-310.

Mudgal, V., A. K. Garg, A.K., R.S. Dass, and V. P. Varshney, 2012. Effect of selenium, zinc, and copper supplementation on blood metabolic profile in male buffalo (Bubalusbubalis) calves. Biological Trace Element Research, 145(3): 30411.

Nayyar, S., V. K. Gill, V. S. Malik, K. S. Roy, and R. Singh, 2003. Vitamin E and selenium improve the blood biochemical composition of anoestrous buffalo heifers. Indian Journal of Animal Science, 73: 654-656.

Nishi, Y., 1996. Zinc and growth. Journal of The American College of Nutrition, 15: 340-344.

NRC, 2000. Nutrient requirements of beef cattle. $7^{\text {th }}$ edition, National Academies Press, Washington D. C.

Om, A. S., and K. W. Chung, 1996. Dietary zinc deficiency alters 5 alpha-reduction and aromatization of testosterone and androgen and estrogen receptors in rat liver. Journal of Nutrition, 126: 842-848.

Padilla, L., T. Matsui, Y. Kamiya, M. Tanaka, and H. Yano, 2006. Heat stress decreases plasma vitamin $\mathrm{C}$ concentration in lactating cows. Livestock Science, 101: 300-304.

Ronchi, B., G. Stradaioli, A. VeriniSupplizi, U. Bernabucci, N. Lacetera, P. A. Accorsi, A. Nardone, and E. Seren, 2001. Influence of heat stress or feed restriction on plasma progesterone, oestradiol-17a, LH, FSH, prolactin and cortisol in Holstein heifers. Livestock Production Science, 68: 231-241.

Sales, J.N.S., R.V.V. Pereira, R. C. Bicalho, and P. S. Baruselli, 2011. Effect of injectable copper, selenium, zinc and manganese on the pregnancy rate of crossbred heifers (Bos indicus $\times$ Bos taurus) synchronized for timed embryo transfer. Livestock Science, 142 (1-3): 59-62. 
Sartori, R., G.J. Rosa, and M. C. Wiltbank, 2002. Ovarian structures and circulating steroids in heifers and lactating cows in summer and lactating and dry cows in winter. Journal of Dairy Science, 85: 2813-2822.

SAS., 2004. SAS/STAT 9.1 User's Guide. Statistical Analysis System. Institute, Inc. Cary., NC.

Sattar, A., R. H. Mirza, and S. M. I. Hussain, 2007. Effect of prepartum treatment of vitamin $\mathrm{E}-$ selenium on postpartum and reproduction and production performance of Exotic cows their calves under subtropical condition. Pakistan Veterinary Journal, 27(3): 105-108.

Scherf, H., L. J. Machlin, T. M. Frye, B. A. Krautmann, and S. N. Williams,1996. Vitamin E biopotency: Comparison of various 'naturalderived' and chemically synthesized $\alpha$ tocopherols. Animal Feed Science and Technology, 59 (1-3): 115-126.

Segerson, E.C., W. R. Getz, and B. H. Johnson, 1981. Selenium and reproductive function in boars fed a low selenium diet. Journal of Animal Science, 53: 1360-1367.

Segerson, E.C., G. Jr Riviere, T. R. Bullock, S. Thimaya, and S. N. Ganapathy, 1980. Uterine contractions and electrical activity in ewes treated with selenium and vitamin E. Biology of Reproduction, 23(5) : 1020-1028.

Senosy, W., and T. Osawa, 2013. Association among calving season and measures of energy status, resumption of ovulation and subclinical endometritis in early lactating dairy cows Animal Reproduction, 10 (1): 24-31.

Sheikh,A.A., A. B. I. Aggarwal, and O. Aarif, 2017 .Inorganic zinc supplementation modulates heat shock and immune response in heat stressed peripheral blood mononuclear cells of periparturient dairy cows. Theriogenology, 95: 75-82.

Sheldon, I.M., and H. Dobson, 2000. Effect of administration of eCG to postpartum cows on folliculogenesis in the ovary ipsilateral to the previously gravid uterine horn and uterine involution. Journal of Reproduction and Fertility, 119: $157-160$.

Sheldon, I.M., D. E. Noakes, A. N. Rycroft, D. U. Pfeiffer, and H. Dobson, 2002. Influence of uterine bacterial contamination after parturition on ovarian dominant follicle selection and follicle growth and function in cattle. Reproduction, 123: 837-845.

Shi, L., Ren, Y., C. Zhang, W. Yue, and F. Lei, 2017. Effects of maternal dietary selenium (Seenriched yeast) on growth performance, antioxidant status and haemato-biochemical parameters of their male kids in Taihang Black goats. Animal Feed Science and Technology, 231: 67-75.

Singh, R., S. S. Randhawa, and K. S. Dhillon, 2002. Changes in blood biochemical and enzyme profile in experimental chronic selenosis in buffalo calves (Bubalus bubalis). Indian Journal of Animal Science, 72: 230- 232.

Sordillo, L.M., and S. L. Aitken, 2009. Impact of oxidative stress on the health and immune function of dairy cattle. Veterinary Immunology and Immunopathology, 128: 104-109.

Turk, R., O. Podpecan, J. Mrkun, Z. Flegar-Mestric, S. Perkov, and P. Zrim, 2015. The effect of seasonal thermal stress on lipid mobilization, antioxidant status and reproductive performance in dairy cows. Reproduction in Domestic Animals, 50: 595-603.

Underwood, E.J., 1981. The incidence of trace element deficiency diseases. Philosophical Transactions of the Royal Society London B. Biological Sciences, 14, 294 (1071):3-8

Vallee, B.L., and K. H. Falchuk, 1993. The biochemical basis of zinc physiology. Physiological Review, 73: 79-118.

Vierk, J.E.1., T. R. Hansen, K. J. Austin, E. A. Van Kirk, B. W. Hess, and W. J. Murdoch, 1998. Inhibition by tocopherol of prostaglandininduced apoptosis in ovine corpora lutea. Prostaglandins Other Lipid Mediators, 56 (5-6): 265-276.

Wilson, S.J., R. S. Marion, J. N. Spain, D. E. Spiers, D. H. Keisler, and M. C. Lucy, 1998. Effects of controlled heat stress on ovarian function of dairy cattle:1. Lactating cows. Journal of Dairy Science, 81: 2124-2131.

Wolfenson, D., Z. Roth, and R. Meidan, 2000. Impaired reproduction in heat-stressed cattle: basic and applied aspects. Animal Reproduction Science, 60-61: 535-547.

Wolfenson, D., H. Sonego, A. Bloch, A. ShahamAlbalancy, M. Kaim, Y. Folman, and R. Meidan, 2002. Seasonal differences in progesterone production by luteinized bovine thecal and granulosa cells. Domestic Animal Endocrinology, 22:81-90.

Yildiz, A., F. Gurdogan, and E. Balikci, 2015. Effect of injection of vitamin $\mathrm{E}$ and selenium administered immediately before the ovsynch synchronization on conception rate, antioxidant activity and progesterone levels in dairy cows. Bil. Vet. Derg, 29 (3):183 - 186. 


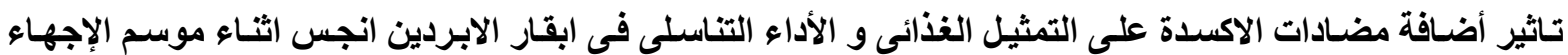

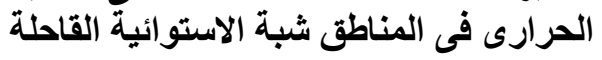

\author{
أيمن يوسف كساب' ، حاتم حمدون '، وليد سنوسى على '، حسن دغشّ ، أحمد سليمان'
}

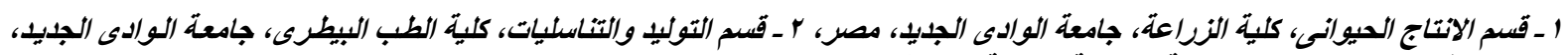

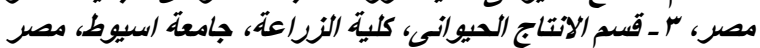

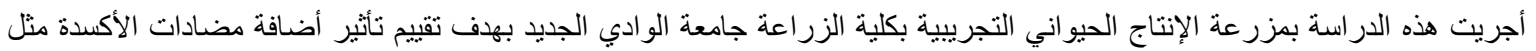

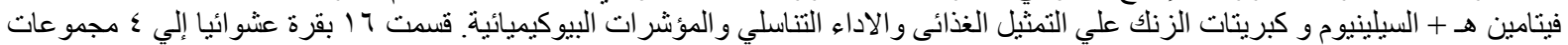

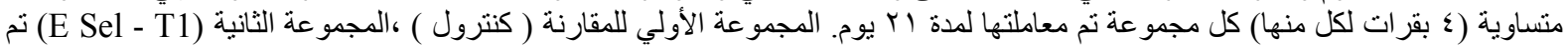

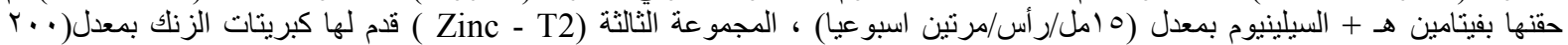

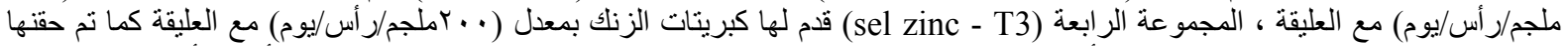

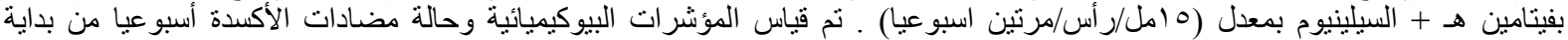

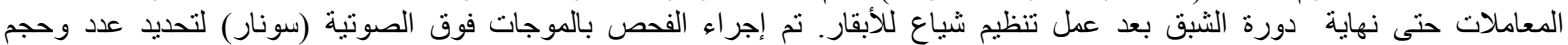

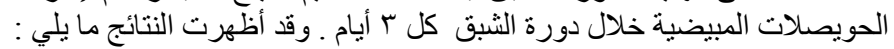

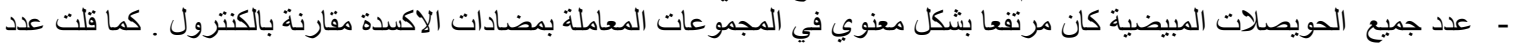

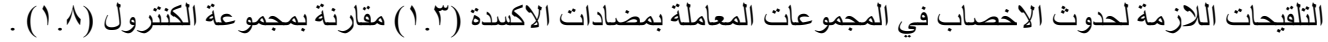

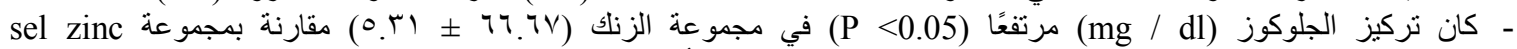

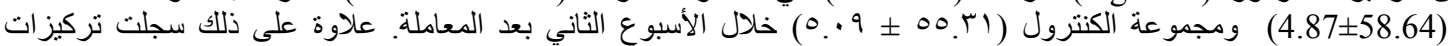
ع و مEFA ك و 0 و 7 و و V بعد المعاملة.

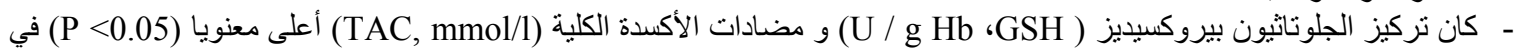

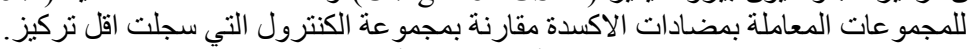

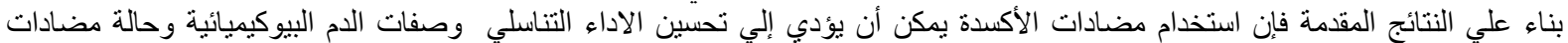

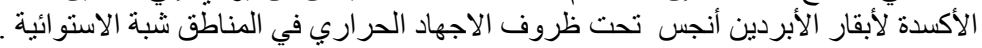

